\title{
EVALUATION OF STAFFING STRENGTH OF COLLEGES OF EDUCATION IN NIGERIA
}

\section{Dr. HAMZA ALHAJI SULAIMAN}

\begin{abstract}
This study evaluated the staffing strength of Colleges of Education in Nigeria. The survey research design was employed. The population was made of four groups that comprised of all the management staff of the colleges 528, all the academic staff 3684, all the non-academic staff 9101 and all the senior staff of the National Commission for Colleges of Education (NCCE) 86 totaling to 13,399. Using both randomization and random stratified sampling techniques a rounded sample of 1000 respondents were selected and used. The distribution was a total of 156 Management staff, 410 Academic staff, 409 Non-academic staff and 25 NCCE officials. A structured questionnaire on five point Likert rating scale was administered. The null hypothesis was tested using One-way Analysis of Variance (ANOVA). A post-hoc Schaffers' test was conducted that showed the extent of their difference. The findings of the study indicated that staffing strength is inadequate more especially when compared to the NCCE stipulated staff-student ratios. Therefore, recommendations include a massive recruitment of academic staff and an urgent implementation of the migration accord of condition of service of these colleges to that of the university nation-wide.
\end{abstract}

\section{Introduction}

The Colleges of Education are the main institutions purposely designed for teacher training in Nigerian educational system. In the National Policy on Education (2013) revised edition, these colleges are listed under Teacher Education as the first category of institutions charged with the responsibility of production of teachers for our primary, junior and senior secondary levels of education. Indeed, the objectives of establishing Colleges of Education stipulated in Decree No. 4 of 1986 are as follows:

a. To provide full-time courses in teaching instruction and training:

i. In technology applied science, commerce, arts, social science, humanities and management.

ii. In such other fields of applied learning relevant to the needs of the development of Nigeria in the areas of industrial and agricultural production and distribution and for research in the development and adoption of techniques;

b. conduct courses in education for qualified teachers;

c. arrange conferences, seminars, and workshops relative to the fields of learning specified in paragraph "a" above (Ajayi, 1995).

Colleges of Education are thus established by provisions of decrees or edicts/laws enacted by the founding authorities. These enabling regulations establish ownership and possession of the colleges for the authorities as well as give the institutions the required measure of autonomy to operate efficiently. Specifically, these edicts, laws or decrees provide for the following among others: 
i. Establishment and objectives of the college.

ii. Principal Officers and their functions.

iii. Appointments and conditions of service.

iv. Governing council.

v. Division of colleges into schools.

vi. Congregation.

vii. Financial provision

viii. Students and their discipline.

ix. Miscellaneous provision such as statutory committees, Right of Appeal etc. (NCCE, 1992).

In 1999, Nigeria returned to civilian rule. The first tenure of political office holders of four years ended in 2003. This period witnessed significant development in the education sector and specifically in Nigerian Colleges of Education. More Colleges of Education were established across the country by both the federal and state governments. Private entrepreneurs and cooperative bodies also established more colleges within the period. The old Colleges of Education, especially the Federal Colleges, also witnessed significant expansion.

This brought about new administrative challenges in the administration of Colleges of Education. Certain important policies of control were formulated. Many colleges got functional governing councils that promoted the clamor for autonomy. There was the introduction of uniform admission through the JAMB. There was the enhancement of salary of staff that attracted many into the system. The democratic political dispensation also allowed the staff unions to agitate for better conditions of service. These and several other similar developments added to the administrative challenges of these colleges.

In the same vain concerned citizens continue to decry the lowering standard of the N. C. E. teachers produced by these colleges. Some commentators often go further to cast doubts on the credibility of both the admissions and the examinations conducted by the colleges. Yet some others critically speak of other administrative lapses in terms of the colleges' decisionmaking process, inefficient establishment of the medium of communication and irregular supervision of instructions. The dilapidation of inadequate staff and students' welfare facilities are easily observable in most of the campuses of these colleges. It is against this background that the study is set out to evaluate the performance of the Administration of Colleges of Education in Nigeria in respect of staffing strength of the Colleges.

\section{Review of Literature}

The importance of quality staffing in the overall performance of an organization cannot be over-emphasized. Thus all organizations should have definite and established procedures and processes of staffing themselves. There has to be definite requirements for the different categories of staff needed in the organization. There has to be definite personnel policies and practices that enable the organization to contentiously attract and secure talented personnel of the desired quality and quantity. That obligation is on the Ministries of Education and educational establishments like institutions of high learning. The Teacher Education Sector 
of the Education System is particularly charged in this task of ensuring quality staffing in all its institutions. As rightly observed by Ukeje (2009) that the recruitment of competent teachers into the teaching profession is probably the most significant problem confronting education all the world over today. There are serious obstacles that must be overcome before recruitment problems can be solved in education.

In Teacher Educational Institutions like Colleges of Education, the requirements are more pronounced for they are training grounds. The main categories of staff in Colleges of Education are the management, the academic and the non-academic staff.

Requirements for the head of the management, the provost, as given by NCCE Minimum Academic Standard (2012) are a Master degree plus teaching qualification and not less than 10 years of teaching and administrative experience. In respect of the Academic staff qualifications, the minimum standards stipulate as follows:

1. Every Academic staff should be a professionally qualified teacher (with a minimum of NCE or PGDE)

2. A good Bachelor's degree (not less than second class lower division in the relevant discipline as the minimum qualification for appointment as lecturer III or its equivalence.

3. Higher National Diploma (HND) holders with a minimum of merit are qualified to be appointed instructors, and

4. Higher degrees or additional professional qualifications in the relevant discipline as added advantages.

The recommended staff/student ratio is 1:25 for Education in view of the fact that all students in the colleges offer the programme. For the non-academic staff, the minimum standard stipulates for every school the details what are required. For example, the (2009) edition states that:

Department and units in the School of Education should be sufficiently staffed with suitable technologists/technicians, electrical and administrative personnel:

For the Special Education unit support staff, it states as follows:

a. Each department requires one typist, one messenger/cleaner and a departmental secretary;

b. Brail lists: it is very important to have an adequate number of brail lists to give the necessary services; and

c. Sign language interpreters: These are also needed in adequate numbers to provide the required services depending on the population of hearing impaired students.

For the Primary Education Studies Department, non-academic staffs required are as follows:

Resource Centre Attendant (1);

A computer Operator with graphics Experience;

A minimum of three Educational Technologists; and

A Secretary, a clerk and a messenger for the head of Department. 
The monitoring and evaluation exercise carried out by the NCCE on Federal Colleges of Education in December 2008, considered the three categories of staff as indicators of performance of the colleges in staffing. The analyses of data collected indicate that all provosts in the Federal Colleges of Education were academically qualified, and that they:

1. Have taught for more than 10 years,

2. Have had administrative experience for more than 10 years,

3. Had been Heads of Department,

4. Have held the position of Deanship of a School in their colleges and

5. Had held the position of Deputy Provost before becoming Provosts.

The analysis also indicted that more than $75 \%$ of the Academic Staff in 18 Colleges have teaching qualifications while in two Colleges, less than $75 \%$ of the academic staff have teaching qualifications. The two Colleges were Federal College of Education (T) Gusau and Federal College of Education (T) Bichi. The analyses considered qualifications of academic staff as good if more than $75 \%$ of the staff in the college have Master's degrees and above with a teaching qualification. On the issue of academic staff/student ratio as prescribed in the minimum standards, 17 or $85 \%$ of the 20 Colleges of Education visited claimed that staff/students ratio in the colleges are in conformity with the minimum standard guidelines. Only Federal College of Education Katsina, Alvan Ikoku College of Education, Owerri, and Federal College of Education (T) Asaba did not have staff-student ratio in accordance with the minimum standards prescriptions.

As for the non-academic staff, data from the exercise indicated that the Academic/nonacademic ratios in 12 out of the 20 colleges covered were as prescribed in the minimum standard guidelines. While in eight or $40 \%$ of the colleges, it was found that academic/nonacademic staff ratios in the various disciplines in their colleges did not conform with the minimum standard guidelines.

The same categories of staff were considered for the same type of exercise on State Colleges of Education in December, 2009. From the analyses of the data collected it became evident that:

1. All the Provosts of State Colleges of Education had taught for more than 15 years at the College of Education level;

2. All the Provosts have administrative experience of ten (10) years and above;

3. Only (1) lacked the minimum requisite qualification of Master's degree.

4. Seven (7) of the provosts had never been Dean of a school and they were those of Delta state C.O.E. Warri, Umar Sulaiman C.O.E. Gashua, Ebonyi S.C.O.E. Ikwo, Benue S.C.O.E. Katsina-Ala, Benue S.C.O.E Oju, Micheal Otedola College of Primary Education Epe and Osun S.C.O.E. Ila-orangun and;

5. Seventeen (17) of the 28 Provosts had never been deputy provost before their appointment. 
On the issue of Academic staff minimum standard prescribed staff/student ratio, the analyses revealed that eleven (11) state Colleges of Education complied fully while 3 of the Colleges fairly complied. Only four (4) were listed who failed to comply with the minimum standard. These were: Umar Suleiman C.O.E. Gashua, Adamu Augie C.O.E. Argungu, Kaduna S.C.O.E. Gidan-Waya and Adamawa S.C.O.E Hong. But on the issue of Academic Staff academic qualification it was revealed that 22 state Colleges of Education fully complied with the preceding prescriptions, while six (6) of the colleges fairly complied and none failed to comply out rightly.

The exercise also looked into conformity with Academic/Non-academic Staff ratio in the State Colleges of Education. Findings indicate that 18 State Colleges of Education fully complied; seven partially complied, while two State Colleges of Education, Adamu, Augie College of Education Argungu and Rivers S.C.O.E Port-Harcourt hardly complied.

\section{Research Questions}

The following are the research questions raised to guide the study.

1. What is the staffing strength of Colleges of Education in Nigeria?

2. Are there laid down staff requirements and procedures for recruitment followed in Colleges of Education in Nigeria?

3. Are there qualified required numbers of all categories of staffs in Colleges of Education in Nigeria?

4. How are the staffs placed against each type and the students in Colleges of Education in Nigeria?

\section{Research Methodology}

The descriptive survey method was used for the study. Five Level Likert scale questionnaire was administered to 26 selected Colleges of Education in the six Geo-political zones of Nigeria. The total population of the identified stakeholders was 13394 from which a round sample of 1000 was used. In the Colleges the identified stakeholders include the Management Staff, the Academic Staff and the Senior Non-Academic Staff. From the National Commission for Colleges of Education senior staffs of relevant departments were used. A total of 156 Management staff, 410 Academic staff, 409 Non-academic staff and 25 NCCE officials were sampled. The data collected were analyzed by use of simple percentage and (ANOVA).

\section{Hypothesis}

The following null hypothesis was formulated to guide the study

There is no significant difference in the opinions of stakeholders on staffing strength of Colleges of Education in Nigeria. 
Below is the analysis of the respondents' responses on the questionnaire of Staffing Strength of Colleges of Education in Nigeria.

Table 1: Opinions of Respondents on Staffing Strength of Colleges of Education in Nigeria.

\begin{tabular}{|c|c|c|c|c|}
\hline \multirow[t]{2}{*}{ Items } & \multirow{2}{*}{$\begin{array}{l}\text { Category of } \\
\text { respondents }\end{array}$} & \multicolumn{3}{|c|}{ Responses } \\
\hline & & Agree & Disagree & Undecided \\
\hline Item 1 & Management staff & $117(86: 7)$ & $12(8.9)$ & $\begin{array}{ll}6 & (4.4)\end{array}$ \\
\hline There are laid down & Academic Staff & $309(91.2)$ & $23(6.7)$ & $7(2.1)$ \\
\hline requirement of staff both & Non-academic staff & $299(94.7)$ & $13(4.1)$ & $4(1.3)$ \\
\hline $\begin{array}{l}\text { Academic and Non- } \\
\text { academic for each } \\
\text { department }\end{array}$ & NCCE officials & $20 \quad(100.00)$ & $00 \quad(0.0)$ & $0 \quad(0.0)$ \\
\hline Item 2 & Management staff & $105(77.8)$ & $14(10.4)$ & $16(11.9)$ \\
\hline There are laid down & Academic Staff & $288(84.9)$ & $21(6.2)$ & $30(8.8)$ \\
\hline procedure for recruitment & Non-academic staff & $276(87.4)$ & $20(6.3)$ & $20(6.3)$ \\
\hline of new staff & NCCE officials & $16 \quad(80.0)$ & $2 \quad(10.0)$ & $2(10.0)$ \\
\hline Item 3 & Management staff & $75 \quad(55.5)$ & $30(22.2)$ & $30(22.2)$ \\
\hline The staff are recruited & Academic Staff & $204(60.2)$ & 66 (19.5) & $69(20.4)$ \\
\hline based on merit & Non-academic staff & $196(62.0)$ & $56(17.7)$ & $64(20.3)$ \\
\hline & NCCE officials & $14 \quad(70.0)$ & $00(0.0)$ & $6(30.0)$ \\
\hline Item 4 & Management staff & $1009(80.8)$ & $20(14.8)$ & $6 \quad(4.4)$ \\
\hline Academic staff have & Academic Staff & $255(75.2)$ & $51 \quad(15.0)$ & $33(9.7)$ \\
\hline minimum of second class & Non-academic staff & $240(75.9)$ & 43 (13.6) & $33(10.4)$ \\
\hline $\begin{array}{l}\text { lower division in their first } \\
\text { degree }\end{array}$ & NCCE officials & $18 \quad(90.0)$ & $00 \quad(00.0)$ & $2 \quad(10.0)$ \\
\hline Item 5 & Management staff & $108(80.0)$ & 17 (12.6) & $10(7.4)$ \\
\hline All academic staff have & Academic Staff & $244(72.0)$ & $60(17.7)$ & $35(10.3)$ \\
\hline educational qualification. & Non-academic staff & $224(70.9)$ & $54(17.1)$ & $38(12.0)$ \\
\hline & NCCE officials & $18 \quad(90.0)$ & $00(0.0)$ & $2(10.0)$ \\
\hline Item 6 & Management staff & $89 \quad(67.9)$ & $19(14.0)$ & $27 \quad(20.0)$ \\
\hline The Departments & Academic Staff & $155(45.8)$ & 68 (20.0) & $116(34.2)$ \\
\hline Maintains the & Non-academic staff & $132(41.7)$ & 77 (24.4) & $107(33.9)$ \\
\hline $\begin{array}{l}\text { recommended staff student } \\
\text { ratio of } 1: 25\end{array}$ & NCCE officials & $(10.0)$ & $11 \quad(55.0)$ & $7 \quad(35.0)$ \\
\hline Item 7 & Management staff & $70 \quad(51.7)$ & $18(13.3)$ & $47 \quad(34.8)$ \\
\hline The departments maintain & Academic Staff & $170(50.1)$ & $48(14.1)$ & $121(35.7)$ \\
\hline the required number of & Non-academic staff & $151(47.8)$ & $16(20.9)$ & $99 \quad(31.3)$ \\
\hline $\begin{array}{l}\text { academic and non- } \\
\text { academic staff. }\end{array}$ & NCCE officials & $(35.0)$ & $11(55.0)$ & $2 \quad(10.0)$ \\
\hline Item 8 & Management staff & $80(59.2)$ & $17(12.6)$ & $38(28.1)$ \\
\hline Adhere to the laid down & Academic Staff & $198(58.5)$ & $76(22.4)$ & $65(19.2)$ \\
\hline procedures and processes & Non-academic staff & $175(55.4)$ & 84 (26.6) & $57(18.0)$ \\
\hline for recruitment exercise. & NCCE officials & $11(55.0)$ & $6(30.0)$ & $3(15.0)$ \\
\hline Item 9 & Management staff & $77(57.0)$ & $12(8.9)$ & $46(34.1)$ \\
\hline Non academic staff are & Academic Staff & $208(61.3)$ & $39(11.5)$ & $92(27.1)$ \\
\hline properly placed in their & Non-academic staff & $186(58.9)$ & $48(15.2)$ & $82(25.9)$ \\
\hline departments. & NCCE officials & $12(60.0)$ & $4(20.0)$ & $4(20.0)$ \\
\hline Item 10 & Management staff & $110(81.5)$ & $12(8.1)$ & $14(10.4)$ \\
\hline There is no role conflict in & Academic Staff & $295(87.0)$ & $24(7.1)$ & $20(5.9)$ \\
\hline the performance of staff in & Non-academic staff & $271(85.7)$ & $27(8.5)$ & $18(5.7)$ \\
\hline discharge of their duties. & NCCE officials & $15(75.0)$ & $3(15.0)$ & $2(10.0)$ \\
\hline
\end{tabular}




\section{Analysis of Data}

From Table 1 above a total of 745 respondent representing 91.9\% agreed to the item statement.

Therefore it is concluded that there are laid down requirements of both academic and nonacademic staff for each department in Nigerian colleges of education.

In the table above responses of respondents on item 2 had it that 685 staff representing $84.5 \%$ agreed with the item statement that there are laid down procedure for recruitment of new staff in Nigerian colleges of education. Therefore is could be concluded that there are laid down procedure for recruitment of new staff in the Colleges of Education.

In table 1 above data of responses of respondents on item 3 is that 485 representing $59.8 \%$ of the respondents agree to the statement that the staff in colleges of education in Nigeria are recruited based on merit. However there is a significant number and percentage of those who disagreed of 152 which is $18.7 \%$ and a significant number and percentage of 169 which is $20.8 \%$ that were undecided. Therefore in view of the above analysis it is not conclusive that staffs are recruited on merit in the Nigerian Colleges of Education.

In the table data of responses of respondents on item 4 a total of 622 respondents representing $76.7 \%$ agreed that academic staff in Nigerian colleges of education have minimum of second class lower division in their first degree.

Data on item 5 of the questionnaire revealed that total of 594 respondents representing $73.2 \%$ agreed that academic staff have educational qualification. Thus it is concluded that academic staff in Nigerian colleges of education have obtained the required education

In Table 1 above data of respondents' responses on item 6 of the questionnaire indicated a total of 378 respondents representing $46.7 \%$ agreed that departments or colleges maintain the recommended staff-students ratio. This however, is a weak majority view which we may not use to generalize but accept as the popular view point.

In Table 1 above data on responses to item 7 of the questionnaire a total of 398 respondents representing $49.1 \%$ agreed to the statement that Nigerian colleges of education maintain the required number of academic and non-academic staff. However the percentage is low therefore is a strong view point that colleges of education do not maintain the required number of academic and non-academic staff.

In Table 1 above data on responses to item 8 in the questionnaire a total of 464 representing $57.2 \%$ agreed to the statement that the colleges adhere to laid down procedures and processes for recruitment exercise. In view of the higher percentage it could be concluded that Nigerian Colleges of Education adheres to the laid down procedures and processes in their recruitment exercises. 
In Table 1 above the data on item 9 a total of 483 respondents representing $59 \%$ agreed to the statement that non-academic staffs are properly placed in their colleges. Based on this higher percentage and lower percentage of $12.7 \%$ of those who disagreed, it is concluded that nonacademic staffs are properly placed in Nigerian Colleges of Education.

In table 1 above data on item 10 shows that 691 respondents representing $85 \%$ of the total agreed that there is no role conflict in the performance of staff in the discharge of their duties. Thus it is concluded that there is no role conflict in the performance of staff in the discharge of their duties in Nigerian Colleges of Education.

Evidently, though there are high percentages of responses that agreed in all most all the ten items on the staffing strength of Colleges of Education in Nigeria it is an indication that staffing is inadequate more especially in the area staff-student ratio.

To test the hypothesis, one way analysis of variance was used and the results are presented in table 2 below.

Table 2: One way Analysis of Variance (ANOVA) on the opinions of respondents on staffing strength of Colleges of Education in Nigerian

\begin{tabular}{lllllll}
\hline \multicolumn{1}{c}{$\begin{array}{c}\text { Source of } \\
\text { variance }\end{array}$} & \multicolumn{1}{c}{$\begin{array}{c}\text { Sum of } \\
\text { squares }\end{array}$} & Df. & Mean squares & F. & P. & $\begin{array}{c}\text { F- } \\
\text { critical }\end{array}$ \\
\hline Between groups & 347.086 & 3 & 115.695 & 3.400 & .017 & 4.07 \\
Within groups & $274,22.817$ & 806 & 34.023 & & & \\
\hline Total & $\mathbf{2 7 , 7 6 9 . 9 0 2}$ & $\mathbf{8 0 9}$ & & & & \\
\hline
\end{tabular}

The Table above revealed that the calculated P. value is .017 which is lower than the 0.05 alpha level of significance that was set for the study. This means that, there was significant difference between the four groups of respondents. Therefore, the null hypothesis which states that there is no significant difference in the opinions of stakeholders on staffing strength of Colleges of Education in Nigeria is rejected. The groups therefore have significant differences in their opinions on the state of staffing strength of Colleges of Education in Nigeria.

To find out the extent of the differences in opinions of respondents, a post-hoc Scheffe- test was used and the result is presented in table 3:

Table 3: $\quad$ Result of Scheffe- test on the Mean scores of the stakeholders on the Hypothesis

\begin{tabular}{|c|c|c|c|c|}
\hline (I) Status & (J) Status & $\begin{array}{c}\text { Mean difference } \\
\mathrm{I}-\mathrm{J}\end{array}$ & Standard error & Significance \\
\hline \multirow[t]{3}{*}{ Management staff } & Non-Academic Staff & 1.67729 & .59974 & .051 \\
\hline & Academic Staff & .52960 & .59362 & .850 \\
\hline & NCCE officials & .77222 & 1.39757 & .959 \\
\hline Non-Academic & Management staff & -1.67729 & .59974 & .051 \\
\hline \multirow[t]{2}{*}{ Staff } & Academic Staff & -1.14769 & .45611 & .097 \\
\hline & NCCE officials & -.90506 & 1.34493 & .929 \\
\hline
\end{tabular}




\begin{tabular}{lllll} 
Academic staff & Management staff & -.52960 & .59362 & .850 \\
& Non-Academic staff & 1.14769 & .45611 & .097 \\
& NCCE officials & .24263 & 1.34221 & .998 \\
NCCE officials & Management staff & -.77222 & 1.39757 & .959 \\
& Non-Academic staff & .90506 & 1.34493 & .929 \\
& Academic Staff & -.24263 & 1.34221 & .998 \\
\hline
\end{tabular}

- $\quad$ The Mean difference is significant at 0.05 level.

The above test result revealed no significant difference between the groups. All the groups are therefore at insignificantly different positions in their opinions on the state of staffing strength of Colleges of Education in Nigeria.

\section{Discussion of Findings}

The findings of this study revealed that staffing strength of Colleges of Education is weak and inadequate, more especially on the area of staff-student ratio of the Colleges. It also revealed that there are clearly outlined requirements, procedures for recruitments and placements of staffs adhered to by the Colleges. However, the Colleges do not maintain the required number of both the academic and non-academic staffs. All staffs are recruited on merit in Nigerian Colleges Education and most of the Academic staffs have the required minimum of second class lower division in their first degree with the education qualification for teaching.

The analysis also revealed that both at the departmental and the College levels the recommended staff- students' ratio is not maintained. This may seemingly be the course of all problems, shortcomings or lapses associated with the college's products. It is obvious that where the ratio students is high inadequate teaching, lecturing or training takes place. Where ever the students' population is high the facilities are over stretched and poor training is recorded.

The test of the hypothesis on the staffing strength of Colleges of Education in Nigeria revealed significant difference in opinions of the respondents group and the hypothesis was rejected. However, the findings were in line with the NCCE monitoring and evaluation exercise reports of 2008 and 2009 which indicated the colleges operate in conformity with the minimum standard guidelines on staffing.

\section{Conclusion}

In the opinions of the stakeholders, all other things been equal, there is a significant shortfall in the required number of academic staff recommended for the population of students in the Colleges as at the period of the evaluation. The staffing strength is weak and therefore need urgent measures to be redress. 


\section{Recommendations}

On the basis of the findings and conclusions of this research work the following recommendations are made:

1. That government and the administrations of the Colleges should as a matter of urgency make all arrangements and embark on massive recruitment of qualified academic staffs in all the Colleges to make-up the shortfall in the NCCE recommended 1:25 ratio of staff-student in General Education.

2. Similar measures should be applied to all other courses recommended ratios especially for the social sciences and arts courses where we have very large population of students in all most all conventional colleges of education.

3. Where there are no enough to employ visiting lecturer arrangements should be made with nearby University lecturers as much as needed and as much as possible.

4. A very important recommendation is that the proposed migration to University condition of service of colleges of education should be implemented in full nationwide to boost the morale of the lecturers.

\section{References}

Ajayi, K. (1995). Reflections on the Nigerian Education System: A college provost perspective. Abeokuta: Osiele Consult Publication Series.

Akhilomen, S. A. (1992). "Teacher Education expectations in the $21^{\text {st }}$ Century" in Nigeria Teacher Today, 1 (2): 40-47

Federal Republic of Nigeria (2013). National Policy on Education. NERDC Press Lagos Nig.

Junaidu, M.I. (2010). The State of Teacher Education in Nigeria and the Way Forward. A paper presented at the Maiden Conference of the Committee of Provosts held on $27^{\text {th }}$ Jan. 2010 at the NCCE Abuja.

Kabir, I. (2005). The Training of NCE Teacher in Nigeria How far, how well? In Nigerian Journal of Professional Teachers, 1 (1): TRC. Abuja.

Muhammad, D. G. (2005). Management of Teacher Education in Nigeria: Issues and challenges. Journal of Educational Management and Planning, 2 (1): May, NAEPAM.

National Commission for Colleges of Education (1992). Newsletter, 1 (1): Kaduna: December, NCCE.

National Commission for Colleges of Education (2002). Minimum standard: National Certificate of Education. Abuja: NCCE.

National Commission for Colleges of Education (2009). Minimum Standard: National Certificate of Education. Abuja: NCCE. 
National Commission for Colleges of Education (2011). Statistical Digest on Colleges of Education in Nigeria. Abuja: NCCE.

Ukeje, B. O. (2009). Educational Administration. Fourth Dimension publishing Co. Ltd. Enugu Nigeria.

Ojo, C. (2009). Funding Tertiary Education in Nigeria. Ibadan University Press. Olanike, S. N.; Kehinde, O. and Debo, A. (2010) Effect of staff in Tertiary institutions; in the Journal of the National Association for Science, Humanities and Education Research, NASHER, 8 (1): June. 